\title{
"Gender specifics of emotional intelligence as a resource for successful HR- management"
}

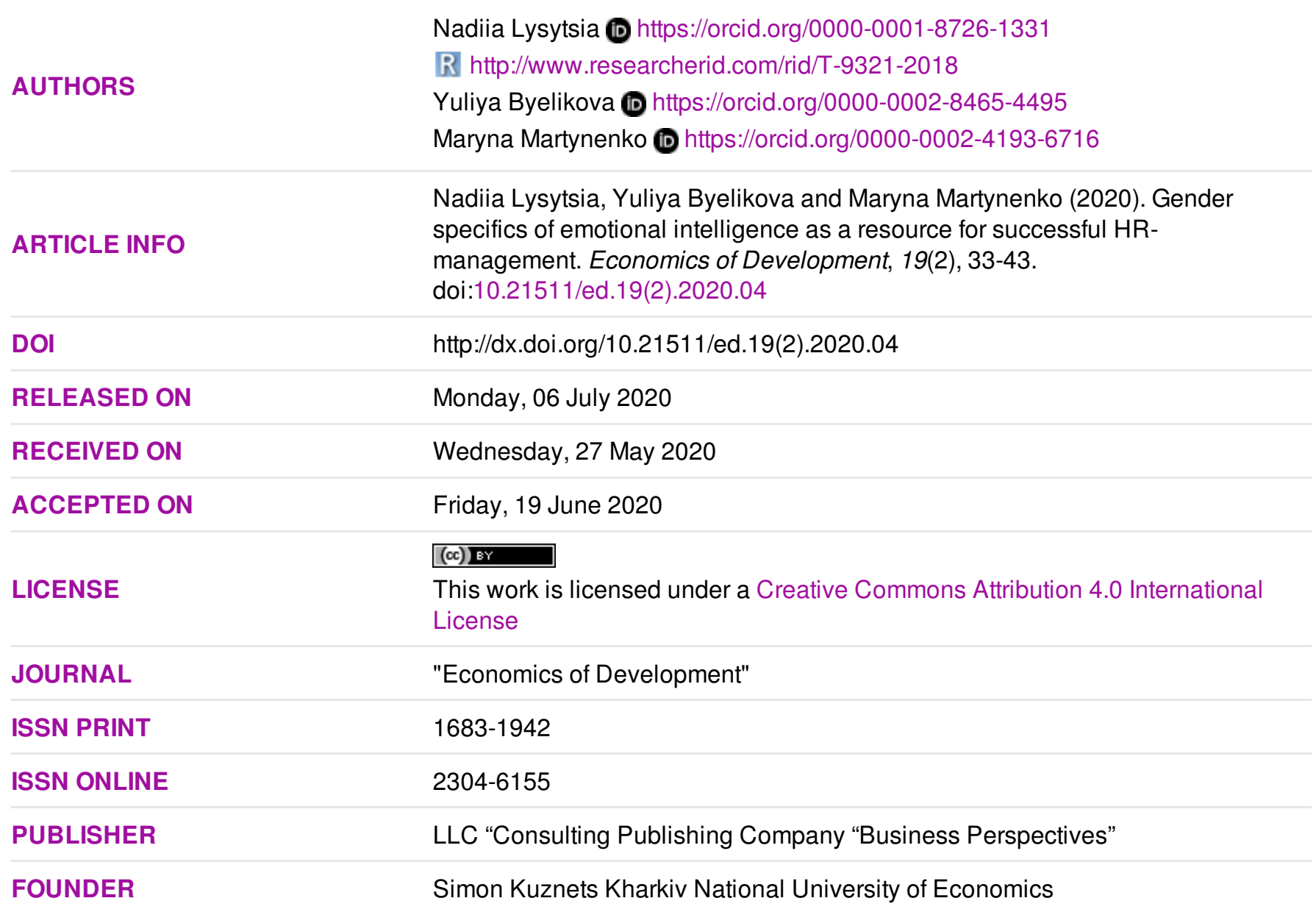

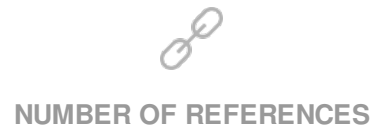

20

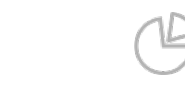

NUMBER OF FIGURES

6

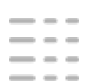

NUMBER OF TABLES

1

(C) The author(s) 2021. This publication is an open access article. 


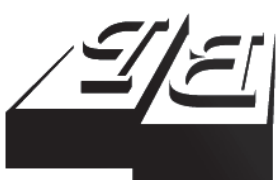

BUSINESS PERSPECTIVES

Publisher

LLC "CPC "Business Perspectives" Hryhorii Skovoroda lane, 10, Sumy, 40022, Ukraine www.businessperspectives.org

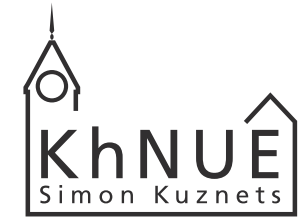

S. KUZNETS KHNUE

Founder

Simon Kuznets Kharkiv National University of Economics, Nauky avenue, 9-A, Kharkiv, 61166,

Ukraine

http://www.hneu.edu.ua/

Received on: 27 th of May, 2020 Accepted on: 19th of June, 2020 Published on: 6th of July, 2020

(c) Nadiia Lysytsia, Yuliya Byelikova, Maryna Martynenko, 2020

Nadiia Lysytsia, Doctor of Sociology, Professor, Simon Kuznets Kharkiv National University of Economics, Ukraine.

Yuliya Byelikova, Ph.D. in Sociology, Associate Professor, Simon Kuznets Kharkiv National University of Economics, Ukraine.

Maryna Martynenko, Doctor of Economics, Professor, Simon Kuznets Kharkiv National University of Economics, Ukraine.

\section{(c) (i)}

This is an Open Access article, distributed under the terms of the Creative Commons Attribution 4.0 International license, which permits unrestricted re-use, distribution, and reproduction in any medium, provided the original work is properly cited.
Nadiia Lysytsia (Ukraine), Yuliya Byelikova (Ukraine), Maryna Martynenko (Ukraine)

\begin{abstract}
Competitive advantage of any successful company is qualified personnel and intellectual capital. Thus, the work of HR-management specialists significantly affects the formation of human resources potential and hence the competitiveness of modern enterprises. In conditions of information economics, information about HR managers is in demand. Together with professional competences HR man agers should use emotional intelligence which can help them to achieve success. Gender specifics of economic specialty students emotional intelligence is not studied enough that substantiates the topicality of the article. In connection with the above mentioned, research related to the study of key professional competencies and emotional intelligence of HR- managers is of particular importance. New technologies for managing behavior of employees appear every decade. As a result, new models of managerial behavior are becoming necessary, which would contribute to the development of new mechanisms for managing people. The aim of the article is to identify gender specifics of the emotional intelligence of economic specialty students as potential workers in the field of HR- management The object of the research is phenomenon of emotional intelligence in the process of HR management. Hall's methodology was used to assess students' emotional intelligence. Results of emotional intelligence research conducted by Hall's methodology allowed the authors to determine practical value of gender specifics of emotional intelligence in HR management. Gender specifics of such components of emotional intelligence (EI) as emotional awareness, management of own emotions, self-motivation, empathy, management of others' emotions, general emotional intelligence have been analyzed. Cluster analysis has been made and allowed the authors to reveal groups of clusters among students with gender specifics of EI which may be regarded as resource for successful HR- management.
\end{abstract}

\section{Keywords}

JEL Classification

gender specifics, emotional intelligence, cluster analysis, resource, HR- management

$\mathrm{J} 16$

Н. М. Лисиця (Україна), Ю. В. Бєлікова (Україна), М. В. Мартиненко (Україна)

\section{ГЕНДЕРНІ ОСОБЛИВОСТІ ЕМОЦІЙНОГО ІНТЕЛЕКТУ ЯК РЕСУРС ДЛЯ УСПІШНОГО УПРАВЛІННЯ ПЕРСОНАЛОМ}

\section{Анотація}

Конкурентна перевага будь-якої успішної компанії - це кваліфікований персонал та інтелектуальний капітал. Таким чином, робота фахівців 3 управління персоналом суттєво впливає як на формування кадрового потенціалу, так і на конкурентоспроможність сучасних підприємств. В умовах інформаційної економіки затребуваною $є$ інформація про менеджерів з управління персоналом. Поряд з професійними компетентностями менеджери з управління персоналом повинні використовувати емоційний інтелект, який зможе допомогти їм досягти успіху. Гендерна специфіка емоційного інтелекту студентів економічної спеціальності недостатньо вивчена, що й обгрунтовує актуальність статті. У зв'язку з вищесказаним особливого значення набувають дослідження, пов'язані з вивченням ключових професійних компетностей та емоційного інтелекту менеджерів 3 персоналу. Нові технології управління поведінкою працівників з'являються щодесятиріччя. В результаті, стають необхідними нові моделі управління поведінкою, які сприяли 6 розвитку нових механізмів управління людьми Мета статті - визначити гендерну специфіку емоційного інтелекту студентів економічних спеціальностей як потенційних фахівців у галузі управління персоналом. Об'єкт дослідження - феномен емоційного інтелекту у процесі управління персоналом. Для оцінки емоційного інтелекту студентів використовували методику Холла. Результати дослідження емоційного 
інтелекту, що були проведені за методикою Холла, дозволили авторам визначити практичну цінність гендерної специфіки емоційного інтелекту в управлінні персоналом. Проаналізовано гендерну специфіку таких компонентів емоційного інтелекту (EI), як емоційне усвідомлення, управління власними емоціями, самомотивація, співпереживання, управління чужими емоціями, загальний емоційний інтелект. Проведений кластерний аналіз дозволив авторам виявити групи кластерів серед студентів 3 гендерною специфікою EI, яка може розглядатися як ресурс для успішного управління персоналом.

\section{Ключові слова} гендерна специфіка, емоційний інтелект, кластерний аналіз, ресурс, управління персоналом

Класифікація JEL $\mathrm{J} 16$

\section{INTRODUCTION}

Today, the main competitive advantage of any successful company is qualified personnel and intellectual capital. In order to attract and retain the most valuable and professional employees, the enterprise must have an effective human resources service or personnel department. The success of maintaining the necessary corporate culture, accumulation of valuable knowledge at the enterprise, creation of preconditions for development of the united and reliable labor collective depends on efficiency of work of this structural division. Thus, the work of HR- management specialists significantly affects the formation of human resources potential, and hence the competitiveness of modern enterprises. In connection with the above mentioned, research related to the study of key professional competencies of HR-managers is of particular importance. Every decade, new technologies for managing behavior of employees appear. People change: managers and employees, whom they are called to manage by virtue of position. As a result, new models of managerial behavior are becoming necessary, which would contribute to the development of new mechanisms for managing people. Employees expect a new attitude from managers. They are focused on full participation in the activities of enterprise. Many of them are ready to take responsibility on equal footing with managers. A generation of employees is being formed who are interested in the long-term and stable success of the enterprise. Such employees are motivated not only by salary, but also by the opportunity to work in a team, to feel like a significant participant in all the events that take place at the enterprise.

In this regard, there is a need to find new ways to manage personnel, as well as to identify potential competencies in demand by employers, ways to form, develop competencies while students of economic specialties are still studying at university. This is confirmed by research done by the scientists at the McKinsey Global Institute (2019). According to the results of research by the scientists of this institute, "the demand for top skills to learn to defend against automation will grow by 2030: advanced IT skills and programming - 91\%, basic digital skills - 69\%, creativity $-40 \%$, leadership and managing others $-33 \%$, entrepreneurship and initiative taking $-33 \%$, technology design, engineering and maintenance - $31 \%$, interpersonal skills and empathy - 30\%, scientific research and development $-28 \%$, advanced communication and negotiation skills $-27 \%$, advanced data analysis and mathematical skills $-25 \%$, adaptability and continuous learning $-24 \%$, information processing and interpretation $-18 \%$, critical thinking and decision making - 17\%, teaching and training others - 14\%". The above mentioned provides a basis for determining the potential competencies of students of economic specialties in HR- management, taking into account gender specifics of their emotional intelligence.

\section{LITERATURE REVIEW}

In the age of the information economy, information as a product becomes important. The information predetermines the decision-making process and allows scientists to analyze the consequences of the performed actions. Any problem in the modern world requires a solution by choosing rational behavior or emotional behavior. Dividing the organizational abilities of the entrepreneur and the personal organization of the entrepreneur, Tomilov (2000) described the differences in the models of their behavior on the basis of primary qualities. Noting the efficiency of the entrepreneur, the scientist identified two groups of qualities of the second level: physiological potential and emotional-volitional potential. At the same time, the scientist expresses the opinion that "the primary qualities of the third level within the emotional-volitional potential have their specific semantic content".

According to Orekhova and the co-authors (2015) the main competencies of the HR- manager are general efficiency, managerial skills, communication skills, mastery of their feelings, intellectual abilities and motivation to work. 
At the same time Caruso, Saloway (2016), Chlevnaya (2012) attribute emotional intelligence to special professional skills (hard skills) of the manager. A similar view is held by Klimov (2004), who considers emotional intelligence as a hard skill in socio-economic professions, that is, requiring active communication. This is exactly the profession of the HR- manager. Isaeva and Mkrtychan (2019) conducted a study of the opinions of HR- managers on such competence as emotional intelligence, and came to a certain conclusion. They believe that "on the one hand, typical for HR managers is the average level of emotional intelligence, and, on the other hand, they highly appreciate the role of emotional intelligence in professional activities". Meshkat, Nejati (2017) explain this gap by traditional ideas about the content of the activities of the HR- manager, but, at the same time, by the unsystematic training programs in this specialty. Scientists analyzed whether emotional intelligence depends on gender. Researches of Lone, Lone (2018) were devoted to the problem "Does emotional intelligence predict leadership effectiveness?" Clarke (2010) studied developing emotional intelligence abilities through team-based learning.

Ahmad, Bangash, Khan (2009) have focused on the analysis of emotional intelligence by gender differences. Scientists note higher rates of emotional intelligence in males compared to females. The research of Mandell and Pherwani (2003), connected with the relationship between emotional intelligence and transformational leadership style deserve some interest. Gender differences in emotional intelligence were analyzed by Bindu and Thomas (2006). The relationship between gender and emotional intelligence was studied by scientists Naghavi and Redzuan (2011). Worth noting is the point of view of scientists Brody and Hall (2008), who studied gender and emotion in context. They believe that it is important to take into account the socio-cultural and situational context. The existing differences are largely explained by the difference in the socialization of females and males, gender stereotypes. The absence of statistical difference by gender was underlined in the State of the Heart Report 2018 (State of the Heart Report, 2018).

Thus, the results of the international research State of the Heart Report 2018 demonstrate that the level of EQ is quite similar among females \& males, at the same time in the structure of emotional intelligence there are major differences in terms of EQ competencies and the outcomes, suggesting different pathways of leverage EQ; for example, females have higher scores related to self-awareness, but lower scores related to decision-making. In general it should be mentioned that on the basis of the Europe scores in 2016-2017, the total EQ score for females is 103.0 (100 is the overall average) and for males is 100 , these score differences are too small to be statistically significant (Global Trends in Emotional Intelligence, 2018). Thus, we can assume that the results of research are largely determined by the methods of the study and the sample size, and the presence/absence of significant statistical differences in emotional intelligence by gender is the consequence of socio-cultural context.

Despite the difference in the research results, the common constant is the presence of gender characteristics in the degree of development of various components of emotional intelligence (some components are more developed in females, others - in males). This difference in the components development eventually creates a balance (low scores on the indicators are offset by high scores on other indicators) and leads to similar final values of emotional intelligence.

First, the need to study gender differences in emotional intelligence is due to the multivariance of existing research results. Secondly, this is due to the necessity to study the presence/absence of the national Ukrainian emotional intelligence gender specifics. Third, it is significant that research on emotional intelligence opens up opportunities not only for a better understanding of human potential, but also for the use of this knowledge for more effective HR-management. As it can be seen from the above analysis, one of the key competencies that affect the manifestations of all others is the HR manager emotional intelligence level, which determines the relevance of the theme of this study.

\section{AIM OF THE RESEARCH. METHODS}

The aim of the article is to identify the gender specifics of the economic university students' emotional intelligence as potential specialists in the field of HR-management. To achieve this aim the following tasks were solved: 1) research of the emotional intelligence of students of economics was done; 2) gender differences of students' emotional intelligence were revealed; 3) specifics of gender differences of students' emotional intelligence as a result of cluster analysis was suggested as the basis for successful HR- management. 
The authors conducted a research of the level of economic specialty students' emotional intelligence. Hall's methodology was used to assess emotional intelligence of students. Hall's methodology was chosen because: 1) it reflects the main components of EQ that were identified and analyzed by Goleman, Bar-On, Meyer and Salovey; 2) it is easy to use. In total, 2013 students (864 students in 2017 and 1,149 students in 2018) participated in the research. The criteria for selecting the respondents were: 1) level of education (bachelors, masters); 2) specialty (economics).

\section{RESULTS}

Managers who work with people must have certain qualities and abilities. These are, first of all, communicative abilities, the ability to manage one's emotions, the ability to manage the emotions of others, the ability to self-motivation, the ability to empathize emotional awareness, etc. The manager shows professional qualities in setting tasks for subordinates, as well as in the process of organizing control over the implementation of their tasks.

The following results were achieved after research of economic specialty students' emotional intelligence. Graduates of economic specialty are regarded by employers as potential managers.. They should have all the competencies necessary for organizing enterprise successful activity. Gender specifics of emotional intelligence may be the resource for success. That is why it was chosen by the authors as the subject for research.

"Emotional awareness" (Figure 1) is the only component of EI for which no statistically significant gender differences were found. This indicates that the ability to realize and understand one's own emotional states is inherent in both females and males mainly at the middle level ( $42.5 \%$ and $42.9 \%$, respectively). $21.1 \%$ of females and $18.4 \%$ of males have a high level of emotional awareness. A rather high percentage of students with a low level of emotional awareness gives pause for thought: $36.5 \%$ females and $38.7 \%$ males. The low level of emotional awareness is the consequence of the prohibition on the expression of emotions in the family, then in the educational institution, ignoring the emotional needs of the professional community. A high level of emotional awareness implies the ability to identify a wide range of emotional states. This skill is formed in the process of primary socialization, when parents name the emotions that the child experiences, which helps to do it later on one's own.

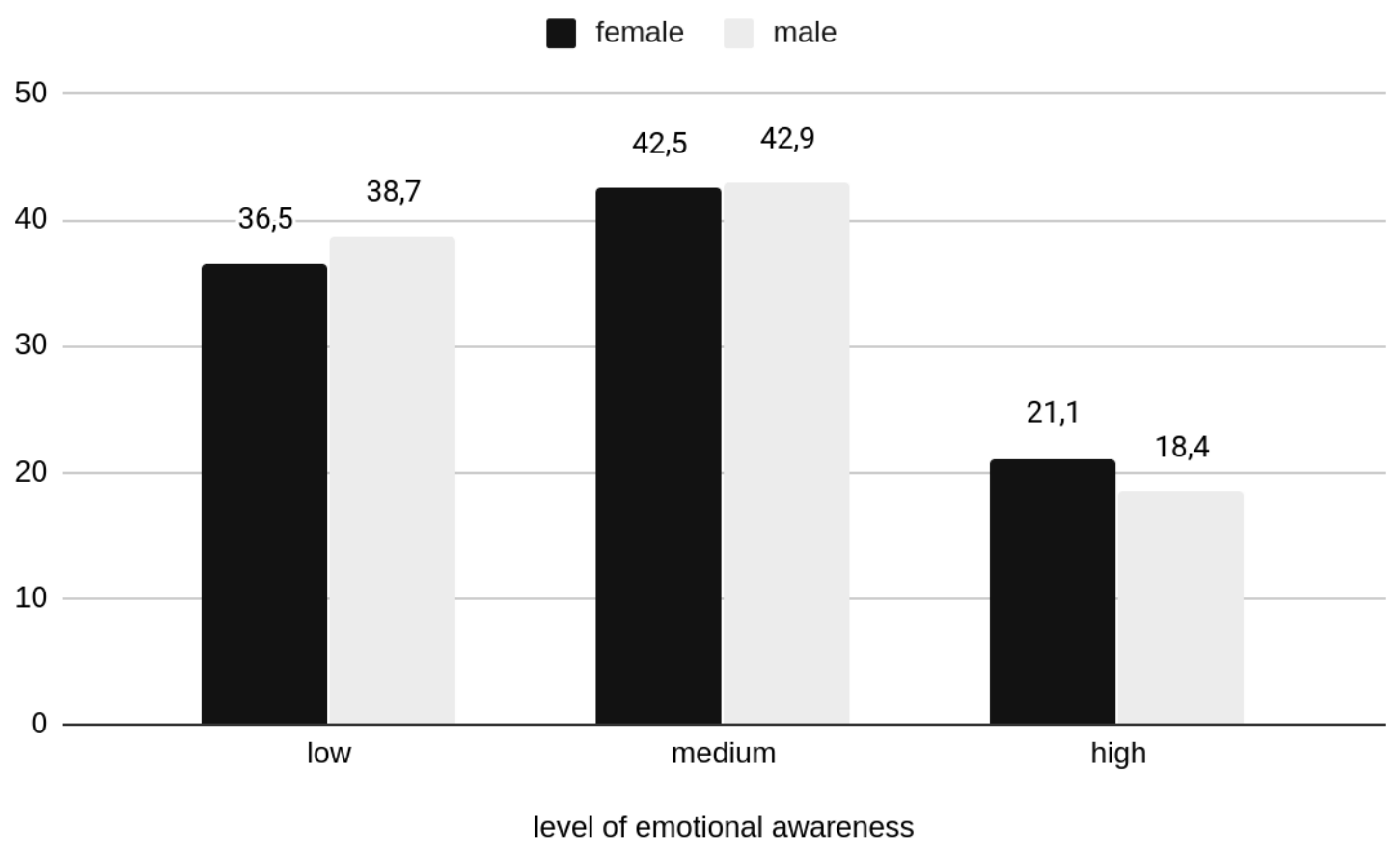

Source: Compiled by the authors on the results of research of students' El.

Figure 1. Emotional awareness (in \%) 


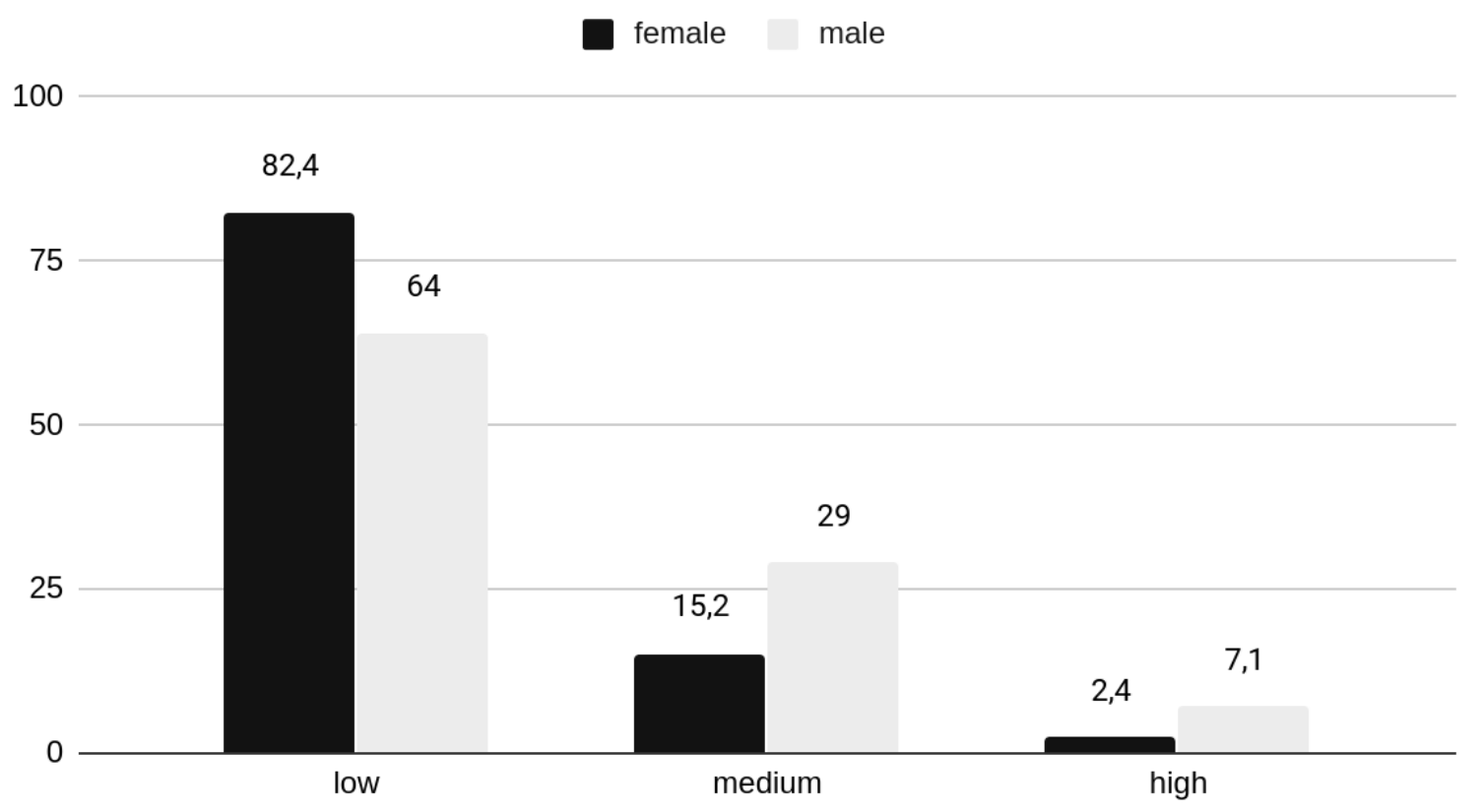

level of management of own emotions

Source: Compiled by the authors on the results of research of students' El.

Figure 2. Management of own emotions (in \%)

The analysis of the data shows statistically significant differences by the component "management of own emotions" (Figure 2). The ability to manage their own emotions in most students is low: females $-82.4 \%$, males $-64 \%$. At the middle level, management of own emotions is developed in $15.2 \%$ of females and $29 \%$ of males. $7.1 \%$ males and $4 \%$ females are characterized by a high level of management of their own emotions.

In general, the level of management of males' own emotions is higher than that of females, and is explained in the following way: in Ukrainian culture, females have more freedom in expressing their emotions. While for males the expression of emotions is taboo. Thus, it is considered normal when a female reacts emotionally to certain situations: laughing or crying. But males from childhood are made believe that the manifestation of emotions is a manifestation of weakness, for example, "do not cry, you're a boy". Practically the only emotion for the manifestation of which there is a ban among females is aggression. While to the manifestation of aggression among the males society is quite loyal. The understanding of femininity associated with emotionality as a manifestation of weakness and masculinity associated with management of one's own emotions is considered a manifestation of strength. This has a negative impact on men's health: high level of stress and inability to overcome it (considered a manifestation of weakness to seek help, including medical).

The fact that most students have a low level of management of their emotions is partly due to age. Younger people are usually more impulsive and prone to emotions than older people. Such a low level of management of one's own emotions indicates a lack of responsibility for one's behavior and a lack of skills to switch to adequate emotional state, to overcome stress.

Statistically significant differences in gender are observed in the emotional intelligence component - "self-motivation" (Figure 3): $48.4 \%$ of females and $43 \%$ of males have a low level of self-motivation; middle level - 39.2\% of females and $38.3 \%$ of males and high level $-12.3 \%$ of females and $14.6 \%$ of males.

In general, males' self-motivation level is higher than that of females. This is due to gender ideals representing the expected behavior of males and females in Ukrainian society. Motivation is understood as an internal driver of human behavior aimed at achieving goals and realizing one's own potential. Social expectations regarding the achievements of males are high in Ukrainian society compared to females: males are expected to have carrier 


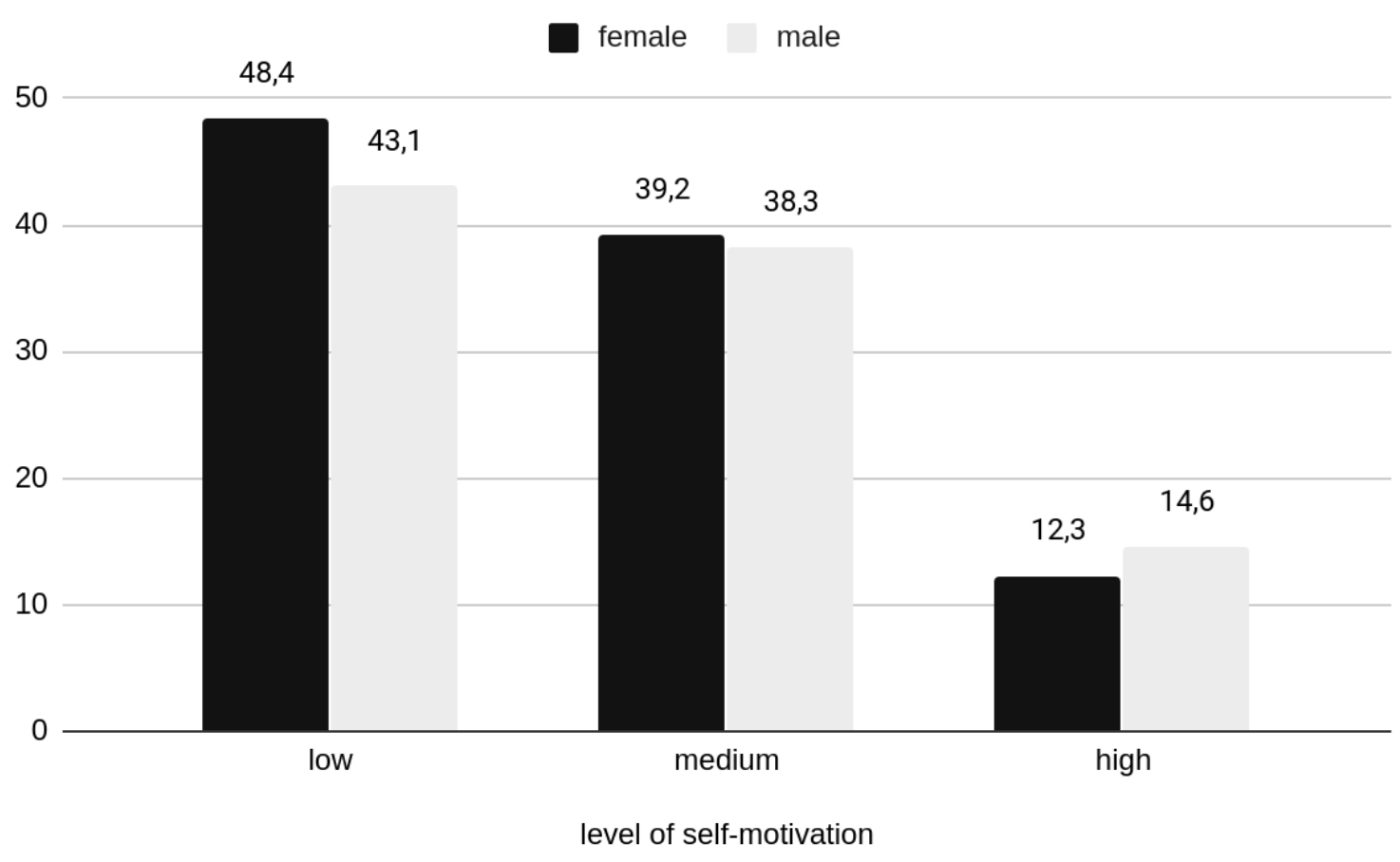

Source: Compiled by the authors based on the results of research of students' El.

\section{Figure 3. Self-motivation (in \%)}

growth, high income, females - family creation and care. In addition, there is a number of negative gender stereotypes about successful females, which become social barriers to building a career in traditionally non-female spheres: politics, industry, etc. Males are oriented mainly at achieving status, females - are oriented at building good relations, non-confrontational atmosphere.

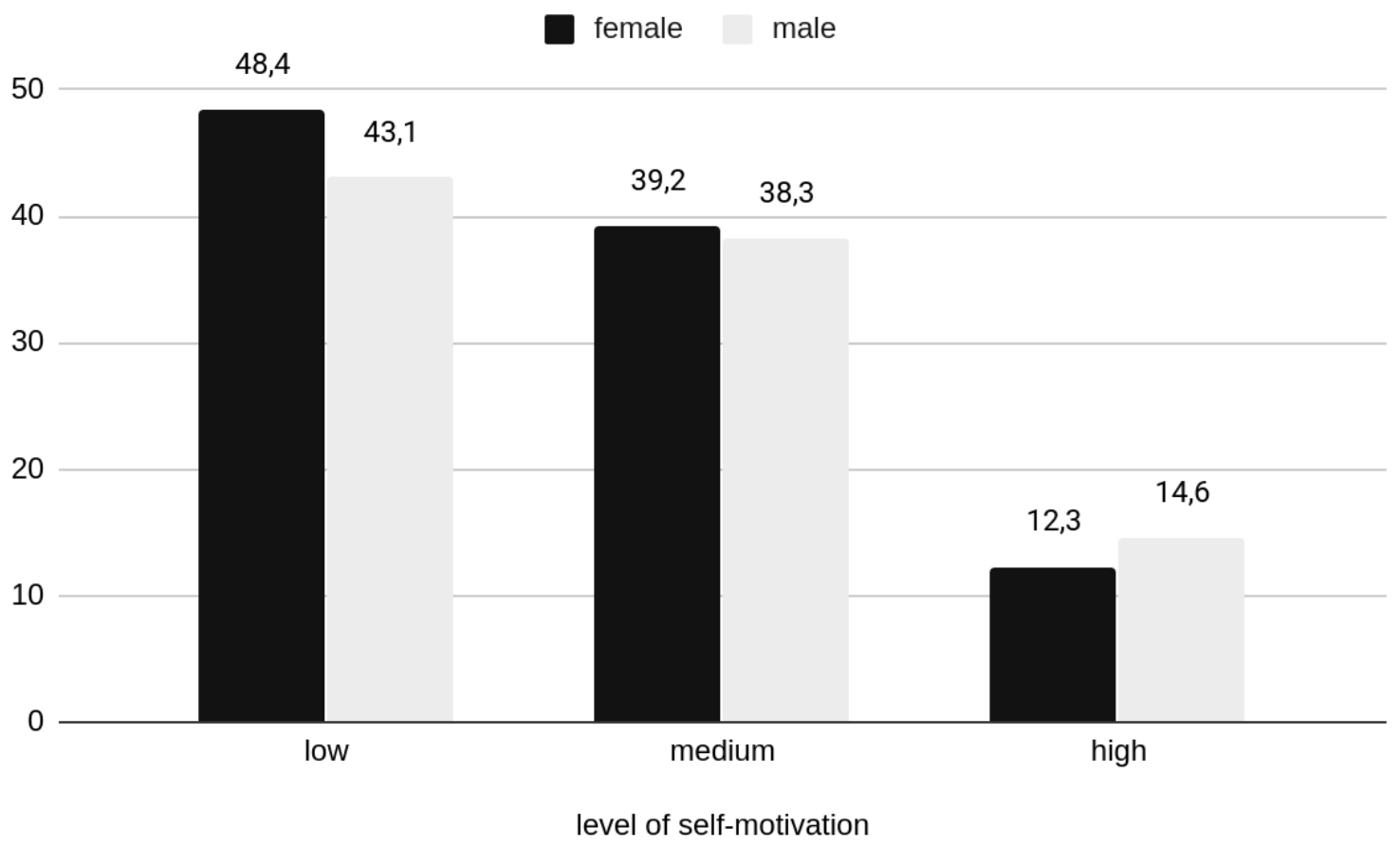

Source: Compiled by the authors on the results of research of students' EI.

Figure 4. Empathy (in \%) 
The component of emotional intelligence - "empathy" (Figure 4) is characterized by the existence of statistically significant differences in gender: $33 \%$ females and $40 \%$ males have a low level of empathy, $44.8 \%$ females and $42.7 \%$ males - middle level, $22.1 \%$ females and $17.3 \%$ males - high level of empathy.

In general, the level of empathy among females is higher compared to males. This difference is caused by gender differences inherent in Ukrainian society: females from childhood aim to build harmonious relationships with others, prepare for the role of a person who cares about others, which involves constant training of empathy skills - the ability to put oneself in another person's shoes. Empathy is necessary in professions that involve constant communication with people - call-center employees, HR- managers. Professions are human-oriented (hairdresser, teacher, psychologist, salesman, etc.) involve emotional behavior, empathy is a component of emotional work. Hochschild (2012), in the monograph "The managed heart: commercialization of human feeling" defines emotional work - as the management of emotions to create publicly visible demonstrations of face and body, emotional work is sold for wages and therefore has an exchange value. The distribution of emotional work in the family is uneven: mostly females take care of children, provide emotional support to other family members, perform the functions of a "home psychologist".

The component of emotional intelligence "management of others' emotions" (Figure 5) is characterized by the existence of statistically significant differences in gender: $37.5 \%$ females and $47.6 \%$ males have a low level of this component, $46.4 \%$ females and $39.3 \%$ males - have a middle level and $16.1 \%$ females and $13.1 \%$ males - high level.

In general, the management of others' emotions is more developed in females than in males. In our opinion, the management of others' emotions is based on the skills of empathy - understanding the emotions of others, and they are more developed in females. Management of others' emotions is aimed at establishing and maintaining relationships with others, which is traditionally expected from females in Ukrainian society. Males are brought up mainly in such a way as to implement a powerful strategy of building relationships - domination (even imposing their desires and needs), while women are expected to submit.

Power-status theory of Kemper (2006) thoroughly explains the influence of status and power on one's own emotions and the emotions of others. An actor with high status is one who receives many benefits and rewards from the other actor(s) in the relationship. We deem it useful to use Weber's (1946, p. 181) definition of power, namely

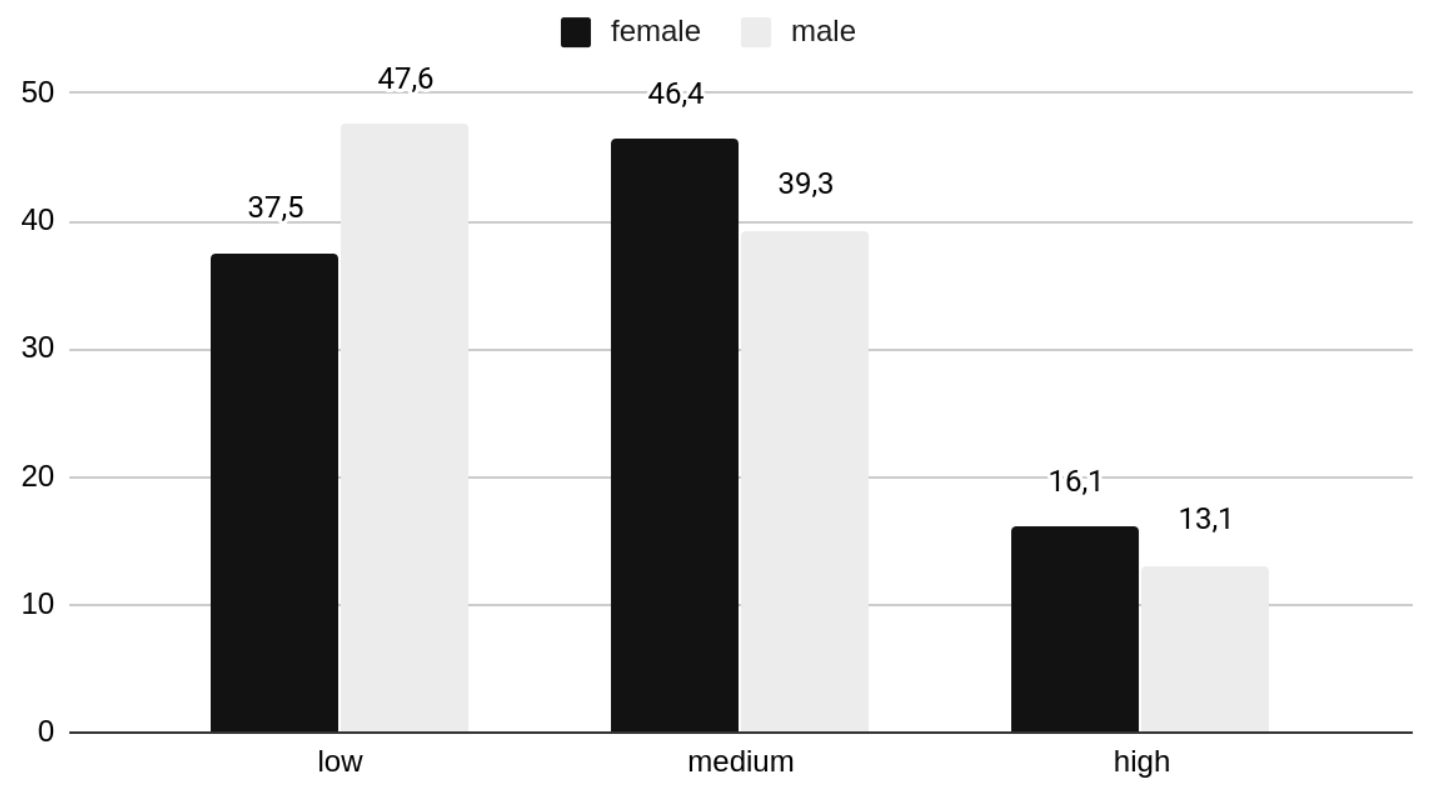

level of management of others' emotions

Figure 5. Management of others' emotions (in \%) 
when actors are able to "realize their own will... even over the resistance of others." Thus, to have power in a relationship is to be able to coerce others to do what one wants them to do even when they do not want to do it.

With power and status definitions in hand, we can employ both to define authority, a concept that partakes of both social relational dimensions. Authority is based on a voluntary allowance (status) of permission to use power in defined circumstances in the relationship.

In general, the EI components focused on themselves (self-motivation, management of their own emotions) are more developed in males, and the EI components focused on others (empathy, management of others' emotions) are more developed in females. This is a reflection of traditional gender roles in Ukrainian society: males focus on their own achievements, status, power and females focus on building and maintaining relationships with others, subordination and dependence on others, contribute to the development of skills for learning, guessing the needs of others. In fact, we are talking about the egocentrism of the masculine and the altruism of the feminine.

Characterizing the "general emotional intelligence" (Figure 6), it should be noted the existence of statistically significant differences in gender: 59\% females and 50\% males have a low level of EI, 38.6\% females and 46.5\% males - middle level of EI and 2.4\% females and 3.5\% of males have a high level of EI. The total level of EI is higher in males compared to females. Males show better results by developing components of self-motivation and managing their own emotions, but females have more developed empathy and management of others' emotions.

In general, the fact that most students have a low level of EI is worrying, which indicates the leveling of the development of emotional skills both in the process of primary socialization (in the family) and during secondary socialization (educational process).

The authors conducted a cluster analysis by the method of k-means with a preliminary hierarchical analysis. As a result, 5 groups of clusters were identified among students who differ in the degree of components' development in the emotional intelligence structure (see Table 1).

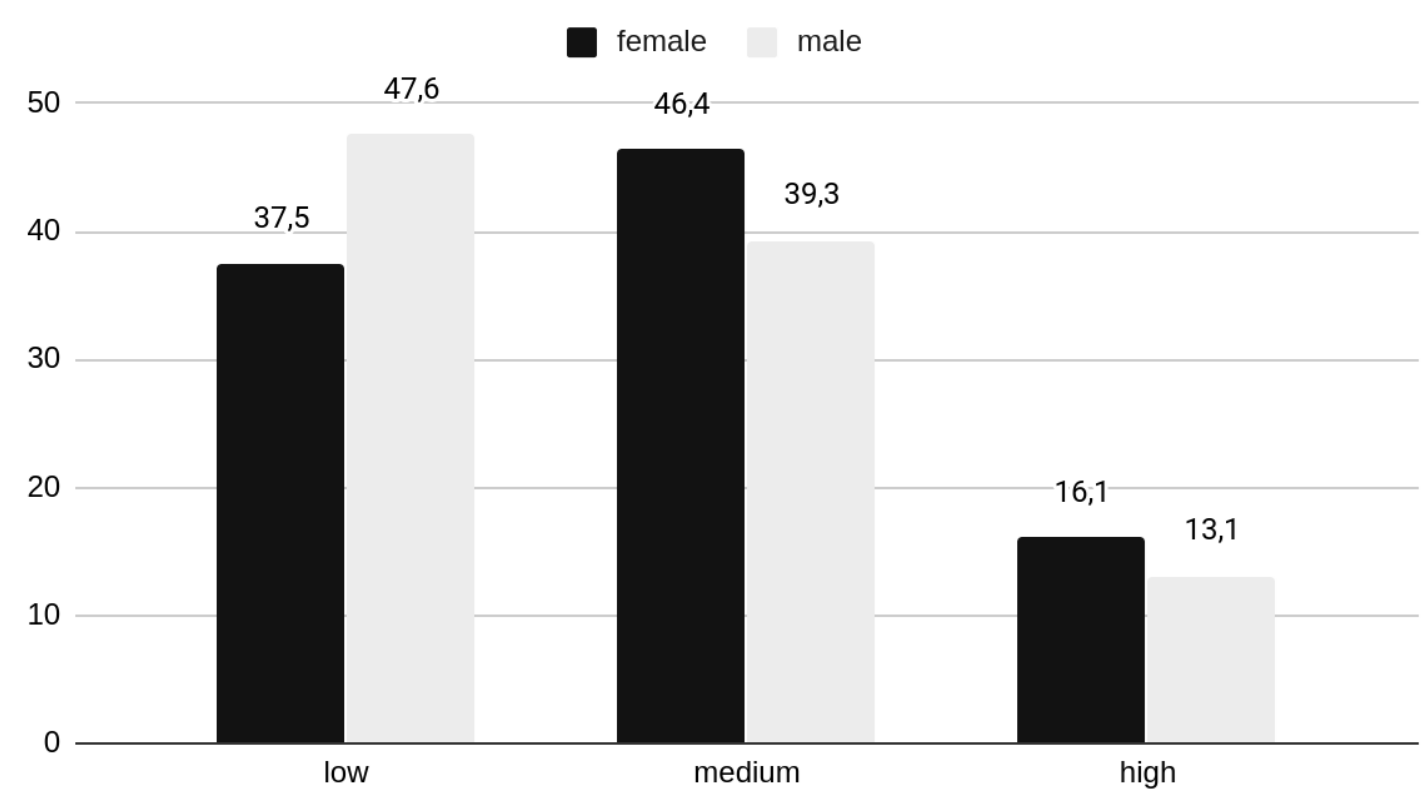

level of management of others' emotions

Source: Compiled by the authors on the results of research of students' EI.

Figure 6. General emotional intelligence (in \%) 
Table 1. Group clusters of students who differ in degree of components' development of EI

Source: Compiled by the authors on the data of cluster analysis.

\begin{tabular}{|c|c|c|c|c|c|}
\hline Characteristics & & & Iuste & & \\
\hline Gender & 1.56 & 1.34 & 1.39 & 1.31 & 1.23 \\
\hline Emotional awareness & 1.62 & 2.82 & 1.28 & 2.46 & 1.69 \\
\hline Management of own emotions & 2.00 & 1.56 & 1.08 & 1.16 & 1.04 \\
\hline Self-motivation & 2.55 & 2.32 & 1.16 & 1.63 & 1.49 \\
\hline Empathy & 1.94 & 2.58 & 1.27 & 1.34 & 2.36 \\
\hline Management of others' emotions & 1.86 & 2.55 & 1.12 & 1.43 & 2.14 \\
\hline
\end{tabular}

The first cluster - self-motivated (goal-oriented) - mostly males with an average level of emotional awareness development, empathy and management of their own and others' emotions, self-motivation are developed at a high level, i.e. the most characteristic feature of the representatives of this group is the focus on achieving the goals and striving to realize their own potential.

The second cluster - emotional leaders - is mainly represented by female students with a middle level of management of their own emotions, a high level of development of emotional intelligence components (emotional awareness, self-motivation, empathy, management of others' emotions). Representatives of this group have the highest level of emotional awareness development, empathy and management of others' emotions compared to representatives of all groups.

The third cluster - emotional outsiders - is represented mainly by females. A characteristic feature of the group is the development of all emotional intelligence components at a low level, including the comparison with representatives of other groups.

The fourth cluster - emotionally aware, is also represented mostly by females. Representatives of this group are characterized by a high level of emotional awareness, a middle level of self-motivation and a low level of management of their own emotions and management of others/ emotions and empathy. Thus, the representatives of this group understand and are able to identify emotions, they are goal-oriented. However, their emotional intelligence is focused on themselves and not on others, which does not allow them to reach the level of management of others' emotions.

The fifth cluster - focused on the other (empaths), mainly females. They are characterized by a high level of emotional intelligence components' development focused on the other - empathy and management of others' emotions. Self-motivation and emotional awareness are developed at the middle level; management of their own emotions - at a low level.

In the structure of all respondents, the representatives of the first group - self-motivated (goal-oriented) are 14\%; representatives of the second group - emotional leaders - 14\%; the third - emotional outsiders - $31 \%$; the fourth emotionally aware - $15 \%$; the fifth - focused on other (empaths) $-26 \%$.

Using the data of the cluster analysis as a base, it is possible to offer recommendations on employment of graduates of economic specialties in the field of HR- management

Self-motivated representatives of cluster 1 will be useful in positions that require strategic planning, since they know how to set goals and look for ways to achieve them. Prospective positions should give them career opportunities, development. A fairly high emotional competence (emotional awareness, empathy and managing emotions of one's own and others) allows them to work with people, solve conflicts in a team, gives good prerequisites for management, which makes them potentially successful in management.

Representatives of the 2nd cluster of emotional leaders have high emotional intelligence, which makes them ideal leaders, diplomats, crisis managers. They can be in demand in positions where you need to be able to show flexibility, speed of switching emotional states, for example, the profession of press secretaries, large business managers. 
The high level of emotional awareness development and empathy will allow them to become potentially successful educators, psychologists, employees of service centers and call centers. It is desirable for representatives of this cluster to be able to communicate with people, which will maximize their strengths.

Representatives of cluster 3 - emotional outsiders are characterized by a low level of emotional intelligence development, which suggests the success of its representatives outside of communication with others. This cluster includes mainly females. Such people are better suited for positions that involve orientation to technology, numbers, and not to communicating with others. Its characteristic feature is the low level of development of all components of emotional intelligence. Due to the low emotional sensitivity in relation to other people, the inability to show flexibility, they can provoke conflict situations, they are hard to cope with crisis situations, work that requires quick reorientation, switching.

Representatives of the 4th cluster - emotionally aware, are characterized by a high level of emotional awareness, a low level of management of their own emotions and emotions of others. Thus, they are likely to be successful in areas that do not require managing people, situations of uncertainty. The ability to recognize and identify emotions makes them good Human Resource managers, analysts, employees of service centers / customer support services, government agencies, social workers, accounting.

Representatives of the 5th cluster - focused on the other (empaths) - are characterized by a high level of development of emotional intelligence components focused on the other - empathy and management of others' emotions, which suggests that they may be ideal workers in the field of education.

\section{CONCLUSION}

Emotional intelligence is one of the important abilities of a specialist, which should be taken into account when choosing a manager whose functional responsibility is HR- management.

However, the possibilities of using the potential of emotional intelligence taking into account gender differences are no less significant. Thus, the results of studies of the gender specifics of the emotional intelligence of students of economic specialties will allow employers to select personnel to ensure the effective successful operation of the enterprise. As a result, this will ensure a decrease in the level of conflict in the team, and will create conditions for participatory management. In addition, using their inherent components of emotional intelligence, managers can quickly organize effective teamwork. The latter, in turn, will become the basis for reducing staff turnover and strengthening the employees' professional competencies in a close-knit community of professionals. Studies of the gender specifics of emotional intelligence on an ongoing basis and the active use of their results can become not only a resource for successful HR- management, but also a resource for further perspective researches looking for ways to save funds for personnel retraining and identifying students as enterprise' potential employees.

\section{AUTHORS CONTRIBUTIONS}

Conceptualization: Nadiia Lysytsia, Yuliya Byelikova, Maryna Martynenko.

Data curation: Yuliya Byelikova.

Formal Analysis: Nadiia Lysytsia.

Funding acquisition: Nadiia Lysytsia, Yuliya Byelikova, Maryna Martynenko.

Investigation: Nadiia Lysytsia, Yuliya Byelikova, Maryna Martynenko.

Resources: Maryna Martynenko.

Validation: Yuliya Byelikova.

Visualization: Nadiia Lysytsia, Maryna Martynenko.

Writing - original draft: Nadiia Lysytsia, Yuliya Byelikova. 


\section{REFERENCES}

1. Ahmad, S., Bangash, H., \& Khan, S. (2009). Emotional intelligence and gender differences. Sarhad J. Agric, 25(1), 127-130. Retrieved from http://www.aup.edu.pk/sj_pdf/EMOTIONAL\%20INTELLIGENCE\%20AND\%20GENDER\%20DIFFERENCES.pdf

2. Bindu, P., \& Thomas, I. (2006). Gender differences in emotional intelligence. Psychological studies-university of Calicut, 51(4), 261-268.

3. Brainapps.io (n.d.). Hall Emotional Intelligence Test. Retrieved from https://brainapps.io/test/holl

4. Brody, L., \& Hall, J. (2008). Gender and emotion in context. In M. Lewis, J. Haviland-Jones, L. Barrett (Eds.), Handbook of emotions (pp. 395-408). NY: The Guilford Press. Retrieved from https://pdfs.semanticscholar.org/504d/b5d29a64cc09f000b19315187c09948f831d.pdf

5. Clarke, N. (2010). Developing emotional intelligence abilities through team-based learning. Human Resource Development, 21(2), 119-138. https://doi.org/10.1002/hrdq.20036

6. GreyCampus (2020). The Top Skills to Learn to Defend Against Automation. https://www.greycampus.com/blog/others/the-top-skills-tolearn-to-defend-against-automation?fbclid=IwAR2eGiH-UlXTd7bwtDWLdm-3H1ftius0GPAg0EXu-IvBfOdVxQDWKIE6cgU

7. Hlevnaya, E. (2012). Rol emotsionalnogo intellekta $v$ effektivnosti deyatelnosti: na primere rukovoditeley [The role of emotional intelligence in performance: on the example of leaders] (Ph.D. Thesis). Moscow: NIU "Higher School of Economics".

8. Hochschild, A. (2012). The managed heart: Commercialization of human feeling (352 p.). Berkeley: Univ of California Press.

9. Isaeva, O., \& Mkrtychan, G. (2019). Emotional intelligence of HR managers: is it really improves management performance? Organizational Psychology, 9(2), 52-69. (In Russian). Retrieved from https://orgpsyjournal.hse.ru/2019-9-2/286838460.html

10. Karuzo, D., \& Selovej, P. (2017). Emotsionalnyy intellekt rukovoditelya: kak razvivat i primenyat [The emotional intelligence of a leader: how to develop and apply] (320 p.). SPb: Piter. (In Russian)

11. Kemper, T. (2006). Power and Status and the Power-Status Theory of Emotions. In J. Stets, J. Turner (Ed.), Handbook of the sociology of emotions (pp. 87-113). By. New York: Springer. Retrieved from https://link.springer.com/chapter/10.1007\%2F978-0-387-30715-2_5

12. Klimov, E. (2004). Psikhologiya professionalnogo samoopredeleniya [Psychology of professional self-determination] (304 p.). Moskva: Akademiya. (In Russian)

13. Lone, M., \& Lone, A. (2018). Does Emotional Intelligence Predict Leadership Effectiveness? An Exploration in Non-Western Context. South Asian Journal of Human Resources Management, 5(1), 28-39. http://dx.doi.org/10.1177/2322093718766806

14. Mandell, B., \& Pherwani, S. (2003). Relationship Between Emotional Intelligence and Transformational Leadership Style: A gender Comparison. Journal of Business and Psychology, 17(3), 387-404. Retrieved from https://link.springer.com/article/10.1023/ A:1022816409059\#: :text=05)\%20was\%20found\%20between\%20gender,of\%20male\%20and\%20female\%20managers.\&text=05)\%20 was\%20found\%20in\%20the\%20transformational\%20leadership,of\%20male\%20and\%20female\%20managers

15. Meshkat, M., \& Nejati R. (2017). Does Emotional Intelligence Depend on Gender? A Study on Undergraduate English Majors of Three Iranian Universities. SAGE Open, 7(3). http://dx.doi.org/10.1177/2158244017725796

16. Naghavi, F., \& Redzuan, M. (2011). The relationship between gender and emotional intelligence. World Applied Sciences Journal, 15(4), 555-561. Retrieved from https://www.semanticscholar.org/paper/The-Relationship-Between-Gender-and-Emotional-Naghavi-Redzu an/63c3184d107e804db1b7701a752f6f27d11b2c56

17. Orekhova, T., Orekhov, V., \& Karandina, I. (2015). HR Manager: New Innovative Requirements for His/Her Expertise. Leadership and Management. 2(3), 191-208. http://dx.doi.org/10.18334/lim.2.3.1740

18. Six Seconds (2018). Global Trends in Emotional Intelligence Europe. Retrieved from https://www.bluegg.nl/resources/SOH-2018-EUROPE.pdf

19. Six Seconds (2018). State of the Heart Report. Retrieved from https://www.6seconds.org/2018/12/04/wellbeing-threats-and-performance-opportunities-the

20. Tomilov, V. (2000). Kultura predprinimatelstva [Enterprise Culture] (368 p.). SPb: Piter. (In Russian) 